\title{
Renal Enzymes and Microglobulins in Patients with Rheumathoid Arthritis
}

\author{
Dejan Spasovski ${ }^{* *}$ and Tatjana Sotirova ${ }^{2}$
}

${ }^{1}$ University Clinic for Rheumatology, Ss Cyril and Methodius University, Skopje, Republic of Macedonia

${ }^{2}$ University Clinic of Hematology, Ss Cyril and Methodius University, Skopje, Republic of Macedonia

\begin{abstract}
Aim: The aim of this study was to detect and compare the enzymes, globulins and reactants of the early phase in patients with untreated rheumatoid arthritis and to reveal the effect of untreated rheumatoid arthritis on tubular function and sensitivity on brush border area.

Material and Methods: The samples of serum and urine were examined in 70 participants (35 patients with untreated rheumatoid arthritis, 35 individuals of the healthy control group). We used in the study the kinetic assay for determination of alanine aminopeptidase (AAP) (Standards methods under IFCC), y-glutamiytransferase and MEIA (Microparticle Enzyme Immunoassay) (Abbot $A_{x}$ sym system) for detection of $\beta$ 2-microglobulin in urine.

Results: Of 35 patients with RA, 16 patients showed presence of $\mathrm{Y}$-GT (sensitivity of the test $-45.71 \%$ ), 24 patients showed presence of AAP enzymuria (sensitivity of the test $-68.57 \%$ ), while the presence of $\beta 2$-microglobulin in urine was very low (sensitivity of the test - $0 \%$ ). From 18 RF negative patients, 14 patients were AAP positive, 10 patients were $y$-GT positive, while the presence of $\beta 2$-microglobulin in urine was not detected. Among 17 RF positive patients with RA, the presence of AAP was detected in 10 patients, the presence of $\mathrm{Y}-\mathrm{GT}$ in 6 patients, while the presence of $\beta 2$-microglobulin in urine was not detected.
\end{abstract}

Conclusion: In untreated rheumatoid arthritis AAP had higher sensitivity than $y-G T$ and $\beta 2$-microglobulin in detection of asymptomatic renal damage.

Keywords: Rheumatoid arthritis; Rheumatoid factor; $\beta 2$ microglobulin; Alanine amino peptidase; g-glutamyl transferase

\section{Introduction}

The urine enzymes usually originate from epithelium cells and glands of urogenital system, plasma, leucocytes, erythrocytes and kidneys [1]. Approximately 40 [2-4] different enzymes from different groups appear in urine: transferases, lyases, oxidoreductases, different isomerases and ligases which usually are not found in urine. The appearance of such great number of enzymes in urine is due to the kidney's dominant function - excretion. Brushed epithelium of proximal tubules is the location for alanine aminopeptidase (AAP) $90 \%$, alkaline phosphatase (AP) $-70 \%$ and $\gamma$-glutamyl transferase $(\gamma$ GT) $-50 \%$ from the total activity of these kidney enzymes [5]. Brushed epithelium is very sensitive even in physiological conditions, thus definite dispensation of superficial enzymes can be used as a marker for renal damage both primary and secondary, caused by drugs or toxins [6]. Tubular lysosomal system is very dynamic system and low level of lysosomal enzymes found in normal urine is a result of normal exocytic and pinocytic activity of tubular epithelial cells [7]. The extent of enzymuria depends on location and damage intensity. Increased enzymatic activity is a reflection of disease activity and kidney's residual functional capacity [8]. Renal tubular damage initially affects lysosomal /plazma cell membrane system, causing enzymatic loss in urine in early phase. Further increase in enzymatic excretion is connected with cell structural damage causing cell necrosis. Elimination of toxic stimulus is followed by reduction of urine enzymatic activity and tubular regeneration. The aim of this study is to define the effect of untreated rheumatoid arthritis on tubular function and sensitivity of brush border epithelium of renal proximal tubules. AAP, $\gamma$-GT and $\beta 2$ - microglobulin $(\beta 2 \mathrm{M})$ in urine are used as indicators for proximal tubular damage.

\section{Markers for Assessment of Renal Damage}

For assessment of asymptomatic renal damage some classes of protein $\mathrm{S}$ in urine are used:
1. Low molecular weight proteins usually filtered in glomerulus and reabsorbed in tubules $(\beta 2 \mathrm{M})$ [9-14].

2. Intermediate proteins normally filtered in glomerulus in very small quantity, while the rest is reabsorbed in tubules (microalbumin, transferin).

3. High molecular weight enzymes, usually not filtered in glomerulus, originating from renal proximal tubules (microsomal AAP, NAG).

Alanine aminopeptidase (AAP) arylamidase amino acid, amino peptidase, $\alpha$-aminoacyl-peptidyl hydrolase (microsomal EC 3.4.11.2, earlier 3.4.1.2) is hydrolytic product of peptides, amides and p-nitroanilide. AAP is found in many tissues such as kidneys, intestine, lung and liver. AAP in different tissues has different electrophoretic conductivity. This enzyme has at least five [5] different isoenzymes, distinguished by immunological and electrophoretic features and ion change chromatography [15]. Normal serum contains only one isoenzyme, while in liver, biliary or pancreatic disease additional fractions are found. The enzyme is found in urine [16].

$\gamma$-glutamyl transferase $(\gamma$-GT), $(\gamma$-glutamyl-peptid aminoacid; $\gamma$-glutamyl-transferase, EC 2.3.2.2, is catalyzing transmission of $\gamma$-glutamyl groups with peptides (as glutathione) and other peptides or amino acides. $\gamma$-GT has an important place in metabolism of

*Corresponding author: Dejan Spasovski, University Clinic of Rheumatology, Ss Cyril and Methodius University, Skopje, Macedonia; Tel: +38965168248; E-mail: drspasovski@yahoo.co.uk

Received June 28, 2014; Accepted October 04, 2014; Published October 10 2014

Citation: Spasovski D, Sotirova T (2014) Renal Enzymes and Microglobulins in Patients with Rheumathoid Arthritis. J Nephrol Ther 4: 185. doi:10.4172/21610959.1000185

Copyright: () 2014 Spasovski D, et al. This is an open-access article distributed under the terms of the Creative Commons Attribution License, which permits unrestricted use, distribution, and reproduction in any medium, provided the original author and source are credited. 
glutathione. High concentrations of enzymes are found in kidneys (renal proximal tubules), pancreas (acinar cells), prostate and liver. $\gamma$-GT is located mainly in external parts of plasma membrane. Isoenzymes of $\gamma$-GT in serum are consequence of different posttranslational modifications such as modification of carbohydrate part of molecule of $\gamma$-GT, formation of complexes with lipoproteins $[17,18]$. Due to the differences in carbohydrate parts of the $\gamma$-GT molecule the isoenzymes are found in different tissues (liver, pancreas, kidney and duodenum). Although the peptide part of enzyme is the same in the tissue that originate, these isoenzymes differ in kinetic, electrophoretic and immunologic features [19]. Renal tubular function could be evaluated by measuring the excretion of low molecular proteins in urine.

$\beta 2$-microglobulin $(\beta 2 \mathrm{M})$ in urine is used for detection of tubular malfunction in glomerulonephritis [20] and is often used as sensitive marker for evaluation of renal function [21-25]. $\beta 2 \mathrm{M}$ is a polypeptide with small molecular weight (11.815 daltons). It contains light chain of main histocompatibility antigen (HLA) and influences the production of rheumatoid factor (IgM class) [26]. $\beta 2 \mathrm{M}$ is found in serum and urine in healthy individuals [27]. $95 \%$ of free $\beta 2 \mathrm{M}$ is ultra-filtrated in renal glomerulus and almost complete $(99.99 \%)$ is reabsorbed via proximal tubular endocytosis and finally is catabolized in amino acid in healthy individuals. Usually it is detected in traces in urine. Disturbance in glomerular filtration leads to increase in serum $\beta 2 \mathrm{M}$, while tubular damage leads to increase in urine $\beta 2 \mathrm{M}$. Serum $\beta 2 \mathrm{M}$ concentration is dependent on GFR and shows significant negative correlation with inulin clearance. Serum $\beta 2 \mathrm{M}$ level could serve as an index of damage intensity of renal glomeruli. In pathological conditions increased amount of $\beta 2 \mathrm{M}$ are excreted in urine. This happens when serum $\beta 2 \mathrm{M}$ concentration exceeds renal threshold. Serum level of $\beta 2 \mathrm{M}$ is dependent on synthesis or excretion in serum and is in relation with clearance. This happens in patients with inflammatory diseases such as rheumathoid arthritis [28], SLE [29], Sjogren's syndrome, Crohn's disease [30], cancer and liver damage. Urine $\beta 2 \mathrm{M}$ concentration can be increased in conditions when reabsorption is decreased due to renal proximal tubule damage. It results in urine $\beta 2 \mathrm{M}$ increased concentration and enables distinction between renal proximal tubular and glomerular damage.

$\beta 2 \mathrm{M}$ is used for GFR and for renal tubular function evaluation, especially for toxic tubular damage caused by heavy metals (cadmium and lead) and as screening test for early detection of Balkan's nephritis in endemic regions. $\beta 2 \mathrm{M}$ is unstable in urine $\mathrm{pH}<6$ and it is recommended the urine to be alkalized with bicarbonates before it is processed. $\beta 2 \mathrm{M}$ is considered the earliest protein in tubular proteinuria. It suggests an asymptomatic renal dysfunction in RA patients.

\section{Material and Methods}

Diagnosis of rheumatoid arthritis (RA) was based of the revised diagnostic criteria for classification of RA, suggested in 1987 by the American Association for Rheumatism (ARA) [31]. Patient has to fulfill 4 out of 7 ACR criteria in order to be included in the group with RA. Criteria from one 1 to four 4 have to be present at least 6 weeks. 70 participants were included in the study: 35 RA patients ( 28 female, 7 male) and 35 participants ( 18 female, 17 male) as healthy control group. Their average age in the group with RA was $56-68$ years $( \pm 6,79)$ (range 40-65 years), but in healthy control group 46,2 years $( \pm 12,49)$ (range 29-65 years). The average period from the beginning of disease was 43,97 months $( \pm 45,23)$ (in interval 1-168). All the participants denied past or present renal disease. Three patients were previously treated with oral steroids, while nobody used NSAIL. The rest of the patients denied drug use before inclusion in the study.

\section{Inclusion criteria}

newly diagnosed patients with RA, not treated, age 18-65 years.

\section{Exclusion criteria}

1. Patients with autoimmune diseases, SLE, uric arthritis, Sjogren's syndrome, mixed conjunction texture disease and vasculitis.

2. Patients with previous history of renal, hematologic, cardiovascular, neurologic, liver and lung damage, diseases of the spleen and thyroid gland.

3. Patients who take drugs from basic line.

4. Patients treated with antibiotics and salicylates in period $<6$ months from the beginning of the study.

5. Patients with arterial hypertension, diabetes mellitus, acute infections, cancer, febrile conditions, AIDS.

6. Patients treated with antihypertensive, diabetic and cardiac therapy.

7. Hypersensitive to some drugs or their component.

8. Patients with previous history for blood transfusion and overweight.

9. Patients with glycemia in 0 spot or increased level of degraded products: creatinine in serum and urine, hematuria/ proteinuria, urea in serum and disorder of hematologic and enzymatic status.

10. Patient's age $<18$ years.

All patients took part voluntarily in the study, so the ethical criteria were fulfilled.

\section{Clinical evaluation of disease activity}

The disease activity was evaluated by subspecialist using DAS 28 index (Disease Activity Score - DAS 28) [32-35]. The index is mathematical formula, so we can get uniquely composed quantitative score, which consists of palpation of painful sensitive joints (max number 28), swollen joints (max number 28), ESR and patient's global assessment of disease activity $(0-100 \mathrm{~mm}$ Visual Analogous Scale - VA ) and the morning stiffness. DAS 28 index is ranked from 0 to 10 and score $<3.2$ ranks the disease as low active. The assessment of glomerular filtration rate (GFR) is calculated with Cockroft \& Gault's formula. [36]

\section{Laboratory Assessment}

Clinical assessment of RA comprised: erythroid sedimentation rate (ESR), complete blood count (CBC) and differential, anti CCP 2, C-reactive protein (CRP), Rheumatoid factor (RF), alkaline phosphatase (AP), aspartate amino-transferase (AST), alanine aminotransferase (ALT), creatine kinase (CK), lactate dehydrogenase (LDH), serum urea and serum creatinine. Samples of urine are taken not only for routine urine analysis, but also for detection of creatinine in urine, AAP, $\gamma$-GT and $\beta 2 \mathrm{M}$.

Serum urea was detected with the "Kassirer" method.

Reference values: 3-7,8 mmol/L.

Creatinine in serum and urine was detected with "Jaffe" method: 
Reference values: serum creatinine - 45 - $109 \mu \mathrm{mol} / \mathrm{L}$; urine creatinine $-7-17 \mu \mathrm{mol} / \mathrm{dU}$.

CRP was detected with agglutination test (Latex CRP test) (BioSystems S.A. Reagens\&Instruments Costa Brava 30, Barselona (Spain) [37-39].

Reference value: $<6 \mathrm{mg} / \mathrm{L}$ CRP in serum.

RF was detected with the agglutination test (Latex RF test) (BioSystems S.A. Reagens\&Instruments Costa Brava 30, Barselona Spain) $[40,41]$.

Reference value: $<8 \mathrm{mg} / \mathrm{L} \mathrm{RF}$ in serum. ESR.

ESR was determined using Westergren's quantitative method for

Reference values: $7-8 \mathrm{~mm}$ for male, $11-16 \mathrm{~mm}$ for female.

Anti CCP 2 (second generation) is detected using the ELISA technology of DIA-STAT ${ }^{\mathrm{TM}}$ Anti-CCP (Axis-Shield Diagnostics).

The test's recommended values: $<0.95$ negative; $\geq 0.95$ to $\leq 1.0$ borderline (repeated test recommend); $>1.0$ positive.

Alanine aminopeptidase (AAP) is detected with kinetic methods similar to those for detection of leucin aminopeptidase. L-alanin4-nitroanilid was used in this method as substratum. Catalytic concentration of AAP is directly proportional of $\mathrm{p}$ - nitroanilin absorption measured on $405 \mathrm{~nm}$.

Reference values: AAP in urine 0.25-0.75 U/mmol creatinine.

$\gamma$-glutamil transpeptidase $(\boldsymbol{\gamma}-\mathbf{G T})$ is detected with IFCC method [42]. The methods of measuring the activity of this enzyme in serum use aromatic amides as substratum $(\gamma$-glutamylanilide and $\gamma$-glutamylnaftilamide). The most often used artificial substratum peptide analog is $\gamma$-glutamyl-p-nitroanilide, offering possibility for kinetic and colorimetric determination of the enzymatic activity $[43,44] . \quad \gamma$-glutamyl-p-nitroanilide later is changed with $\mathrm{L}-\gamma$-3karboksi- 4-nitroanalid (Glukan), because of higher dissolution [45]. As acceptor of the substratum and puffer is used glycin-glycin, getting higher catalytic activity. This method is standardized by International Federation for Clinical Chemistry (IFCC) and is considered as reference method. IFCC method for measurement of the concentration of catalytic activity of $\gamma$-GT in serum and urine is based on the principles developed by Orlowski and Meiser [43] and Szasz [42]. This method has modifications developed by Persijin and Van der Slik [44]. L- $\gamma$-glutamyl-3-carboxi -4-nitroanilide is used as a donor of the substratum. In IFCC method Tris (hydroxymethyl) aminoethane is changed with glycin-glycin, used as a buffer and acceptor of the substratum. Magnesium (Mg) earlier used for keeping L- $\gamma$-glutamyl4-nitroanilide in solution in IFCC method is omitted.

Reference values: $\gamma$-GT in urine: $0.84-1.80 \mathrm{U} / \mathrm{mmol}$ creatinin.

Detection of $\beta 2$-microglobulin ( $\beta 2 \mathrm{M})$ in urine by MEIA method (Microparticle Enzyme Immunoaassay) (Abbot A sym system)

$\mathrm{A}_{x} \operatorname{sim} \beta 2 \mathrm{M}$ detection is based on MEIA technology (Microparticle Enzyme immunoassay), used for quantitative detection of $\beta 2 \mathrm{M}$ in serum, plasma and urine in patients with RA and renal dysfunction. The reaction consists of interaction of $\beta 2 \mathrm{M}$ with anti- $\beta 2 \mathrm{M}$ antibody, forming an interrelated complex. The complex reacts with Matrix cell and is tightly connected to them. A conjugate of alkaline phosphatase is added, which connects with the complex forming sandwich-complex. 4-Methylumbelliferyl Phosphate (4-MUP) is added on this complex; it reacts with alkaline phosphatase from the complex and fluorescent product Methylumbelliferon with light blue color is obtained. The degree of optical fluorescence directly proportionally determines $\beta 2 \mathrm{M}$ concentration. It is determined automatically (Abbot $A_{x}$ sym system). $\beta 2 \mathrm{M}$ is very sensitive to $\mathrm{pH}$ changes in urine, because it decomposes rapidly in low $\mathrm{pH}$ values $(<\mathrm{pH} 6.0)$. So, if the urine is acid, it has to be alkalized.

Reference values: $\beta 2 \mathrm{M}$ in urine $-0.02-0.19 \mathrm{mg} / \mathrm{L}$

\section{Statistical Analysis}

The difference between two arithmetic means was tested with Student's "t-test", comparing the middle values of the certain numerical parameters between two groups. Wilcoxon-matched test was used for independent samples. Sensitivity and prediction for positive and negative test of examined values were defined with the test of sensitivity and specificity. P value under 0.05 was taken as statistically significant. Data processing was done with statistical package -Statistica 7.0.

\section{Results}

Of the 35 patients with RA, 16 patients (45.71\%) showed presence of $\gamma$-GT, 24 patients (68.57\%) presence of AAP enzymuria and no presence of $\beta 2 \mathrm{M}(0 \%)$ in urine. RF appeared in 17 patients $(48.57 \%)$. 6 patients $(17.14 \%)$ were $\gamma$-GT and RF positive, 10 patients were AAP and $\mathrm{RF}$ positive (28.57\%), while $\beta 2 \mathrm{M}$ in urine in RF positive patients showed very low percentage $(0.05 \%)$. From $18 \mathrm{RF}$ negative patients, 10 patients $(28.57 \%)$ were $\gamma$-GT positive, 14 patients $(40 \%)$ were AAP positive, while presence of $\beta 2 \mathrm{M}$ in urine was not detected ( $0 \%)$. Among 7 RF positive patients (20\%) AAP enzymuria was not detected. Among $11 \mathrm{RF}$ positive patients $(31.42 \%) \gamma$-GT was not detected. In $17 \mathrm{RF}$ positive patients (48.57\%) $\beta 2 \mathrm{M}$ was not detected in urine. Of $18 \mathrm{RF}$ negative patients AAP enzymuria was detected in 14 (77.77\%), while in $10(55.55 \%)$ presence of $\gamma$-GT was detected. The presence of $\beta 2 \mathrm{M}$ in urine showed very low percentage $(0 \%)$. From 11 patients without AAP enzymuria, 7 patients (63.63\%) were RF positive. From 19 patients with no presence of $\gamma$-GT enzymuria, 11 patients (57.89\%) were RF positive. From 35 patients without changes in $\beta 2 \mathrm{M}$ concentration in urine, 17 patients (48.57\%) were RF positive. Among $18 \mathrm{RF}$ negative patients, AAP enzymuria was present in 14 patients $(77.77 \%), \gamma$-GT was present in 10 patients (55.55\%), while $\beta 2 \mathrm{M}$ in urine was not present at all (0\%). Among 35 RA patients sensitivity of AAP was $68.57 \%$, sensitivity of $\gamma$-GT was $45.71 \%$, sensitivity of $\beta 2 \mathrm{M}$ was $0 \%$, while sensitivity of RF was $48.57 \%$. Among $17 \mathrm{RF}$ positive patients, the presence of $\gamma$-GT was detected in 6 patients (35.29\%), the presence of AAP was in 10 patients $(58.82 \%)$, while the presence of $\beta 2 \mathrm{M}$ was not detected in urine $(0 \%)$. Among healthy control group 7 patients $(20 \%)$ were AAP positive, 6 patients (17.14\%) $\gamma$-GT positive and 1 patient $(2.85 \%)$ showed presence of $\beta 2 \mathrm{M}$ in urine. RF appeared in 2 patients $(5.71 \%)$ (Table 1 ).

Diagnostic value of alanine aminopeptidase (microsomal AAP), $\gamma$-GT and $\beta 2 \mathrm{M}$ in urine in RA patients

For AAP, $\gamma$-GT and $\beta 2 \mathrm{M}$ and for other laboratory variables in RA, sensitivity, specificity, predictable value for positive and negative test are show in (Table 2). AAP had better diagnostic performances than -GT and $\beta 2 \mathrm{M}$ in terms of sensitivity (sensitivity $68.57 \%$ vs $45.71 \%$ vs $0 \%$ ) and specificity (specificity $80 \%$ vs $82.85 \%$ vs $97,14 \%$ ) in detection of renal tubular damage in untreated RA.

\section{AAP, $\gamma-$ GT and $\beta 2 M$ and DAS 28 INDEX of disease intensity}

Among 35 patients with RA, DAS 28 $>3.2$ was present in 28 patients (80\%). In 17 RF positive patients the presence of DAS $28>3.2$ was in 15 
Citation: Spasovski D, Sotirova T (2014) Renal Enzymes and Microglobulins in Patients with Rheumathoid Arthritis. J Nephrol Ther 4: 185. doi:10.4172/2161-0959.1000185

Page 4 of 8

\begin{tabular}{|c|c|c|c|c|}
\hline & $\begin{array}{l}\text { RA NOT TREATED GROUP } \\
\text { No } 35 \\
\text { VALUE }(M \pm S D)\end{array}$ & $\begin{array}{l}\text { RA sero- } \\
\text { No } 18 \\
\text { VALUE }(M \pm S D)\end{array}$ & $\begin{array}{l}\text { RA sero+ } \\
\text { No } 17 \\
\text { VALUE }(M \pm S D)\end{array}$ & $\begin{array}{l}\text { CONTROL } \\
\text { HEALTHY GROUP No } 35 \\
\text { VALUE ( M } \pm \text { SD ) }\end{array}$ \\
\hline & Positive / Negative & Positive / Negative & Positive / Negative & Positive / Negative \\
\hline $\begin{array}{l}\text { AAP }+>0,75 \\
(\text { U/mmol/creatinin })\end{array}$ & $\begin{array}{l}24 / 11 \\
1,06( \pm 0,54) \\
(0,35-2,46)\end{array}$ & $\begin{array}{l}14 / 4 \\
1,14( \pm 0,48) \\
(0,45-2,46)\end{array}$ & $\begin{array}{l}10 / 7 \\
0,98( \pm 0,59) \\
(0,35-2,30)\end{array}$ & $\begin{array}{l}7 / 28 \\
0,74( \pm 0,43) \\
(0,02-1,75)\end{array}$ \\
\hline $\begin{array}{l}\mathrm{Y}-\mathrm{GT}+>1,80 \\
(\mathrm{U} / \mathrm{mmol} / \text { creatinin })\end{array}$ & $\begin{array}{l}16 / 19 \\
1,80( \pm 0,97) \\
(0,45-4,40)\end{array}$ & $\begin{array}{l}10 / 8 \\
1,81( \pm 0,80) \\
(0,70-3,50)\end{array}$ & $\begin{array}{l}6 / 11 \\
1,79( \pm 1,15) \\
(0,45-4,40)\end{array}$ & $\begin{array}{l}6 / 29 \\
1,51( \pm 0,70) \\
(0,35-2,84)\end{array}$ \\
\hline $\begin{array}{l}\text { ß2 MICROGLOBULIN } \\
+>0,19(\mathrm{mg} / \mathrm{L})\end{array}$ & $\begin{array}{l}0 / 35 \\
0,05( \pm 0,03) \\
(0,01-0,15)\end{array}$ & $\begin{array}{l}0 / 18 \\
0,06( \pm 0,04) \\
(0,01-0,15)\end{array}$ & $\begin{array}{l}0 / 17 \\
0,04( \pm 0,03) \\
(0,01-0,13)\end{array}$ & $\begin{array}{l}1 / 34 \\
0,08( \pm 0,06) \\
(0,02-0,25)\end{array}$ \\
\hline $\begin{array}{l}\text { CREATININE SERUM } \\
\leq 49-109 \geq \mu \mathrm{mol} / \mathrm{L}\end{array}$ & $\begin{array}{l}3 / 32 \\
67,55( \pm 14,76) \\
(41-108)\end{array}$ & $\begin{array}{l}1 / 17 \\
68,24( \pm 14,16) \\
(44-108)\end{array}$ & $\begin{array}{l}2 / 15 \\
66,82( \pm 15,77) \\
(41-99)\end{array}$ & $\begin{array}{l}2 / 33 \\
74,95( \pm 19,72) \\
(44-135)\end{array}$ \\
\hline $\begin{array}{l}\text { CREATININE URINA } \\
\leq 7-17 \geq \mathrm{mol} / \mathrm{dU}\end{array}$ & $\begin{array}{l}9 / 26 \\
10,41( \pm 4,71) \\
(3,1-25,4)\end{array}$ & $\begin{array}{l}6 / 12 \\
9,26( \pm 4,54) \\
(3,1-18)\end{array}$ & $\begin{array}{l}3 / 14 \\
11,62( \pm 4,72) \\
(5,8-25,4)\end{array}$ & $\begin{array}{l}5 / 30 \\
9,15( \pm 4,22) \\
(1,8-20,4)\end{array}$ \\
\hline $\begin{array}{l}\text { UREA SERUM } \\
+\geq 7,8 \mathrm{mmol} / \mathrm{L}\end{array}$ & $\begin{array}{l}4 / 31 \\
5,66( \pm 1,46) \\
(3,00-8,60)\end{array}$ & $\begin{array}{l}0 / 18 \\
5,52( \pm 1,33) \\
(3,00-7,5)\end{array}$ & $\begin{array}{l}4 / 13 \\
5,82( \pm 1,62) \\
(3,80-8,6)\end{array}$ & $\begin{array}{l}1 / 34 \\
4,94( \pm 1,28) \\
(2,50-7,2)\end{array}$ \\
\hline $\begin{array}{l}\text { GFR } \\
+>90 \mathrm{ml} / \mathrm{min}\end{array}$ & $\begin{array}{l}14 / 21 \\
99,19( \pm 24,46) \\
(56,08-157,30)\end{array}$ & $\begin{array}{l}7 / 11 \\
99,19( \pm 24,46) \\
(64,67-142,59)\end{array}$ & $\begin{array}{l}7 / 10 \\
99,19( \pm 25,22) \\
(56,08-157,30)\end{array}$ & $\begin{array}{l}4 / 31 \\
113,80( \pm 30,86) \\
(69,98-177,74)\end{array}$ \\
\hline $\begin{array}{l}\text { DAS } 28 \\
+\geq 3,2\end{array}$ & $\begin{array}{l}28 / 7 \\
4,79( \pm 1,56) \\
(1,85-7,03)\end{array}$ & $\begin{array}{l}13 / 5 \\
4,56( \pm 1,76) \\
(1,85-7,03)\end{array}$ & $\begin{array}{l}15 / 2 \\
5,04( \pm 1,33) \\
(2,47-6,83)\end{array}$ & $\begin{array}{l}0 / 35 \\
0,00( \pm 0,00) \\
(0,00-0,00)\end{array}$ \\
\hline $\begin{array}{l}\text { MORNING STIFFNESS } \\
+>0 \mathrm{~min}\end{array}$ & $\begin{array}{l}26 / 9 \\
43,20( \pm 65,13) \\
(0-300)\end{array}$ & $\begin{array}{l}14 / 4 \\
57,50( \pm 81,40) \\
(0-300)\end{array}$ & $\begin{array}{l}12 / 5 \\
28,05( \pm 38,72) \\
(0-120)\end{array}$ & $\begin{array}{l}0 / 35 \\
0,00( \pm 0,00) \\
(0,00-0,00)\end{array}$ \\
\hline $\begin{array}{l}\mathrm{RF} \\
+30 \geq \mathrm{IU} / \mathrm{ml}\end{array}$ & $\begin{array}{l}17 / 18 \\
346,15( \pm 625,22) \\
(0,00-1920)\end{array}$ & $\begin{array}{l}0 / 18 \\
0,00( \pm 0,00) \\
(0,00-0,00)\end{array}$ & $\begin{array}{l}17 / 0 \\
712,67( \pm 743,72) \\
(30-1920)\end{array}$ & $\begin{array}{l}2 / 33 \\
13,71( \pm 38,73) \\
(0,00-120)\end{array}$ \\
\hline $\begin{array}{l}\text { CRP } \\
+12 \geq \mathrm{mg} / \mathrm{L}\end{array}$ & $\begin{array}{l}14 / 21 \\
46,86( \pm 79,19) \\
(0,00-384)\end{array}$ & $\begin{array}{l}3 / 15 \\
8,66( \pm 24,62) \\
(0,00-96)\end{array}$ & $\begin{array}{l}13 / 4 \\
87,31( \pm 96,44) \\
(0,00-384)\end{array}$ & $\begin{array}{l}4 / 31 \\
5,48( \pm 12,80) \\
(0,00-48)\end{array}$ \\
\hline $\begin{array}{l}\text { ESR } \\
+\geq 16\end{array}$ & $\begin{array}{l}27 / 8 \\
48,62( \pm 39,81) \\
(2,0-120)\end{array}$ & $\begin{array}{l}13 / 5 \\
43,94( \pm 39,82) \\
(2,0-120)\end{array}$ & $\begin{array}{l}14 / 3 \\
53,58( \pm 40,39) \\
(5,0-120)\end{array}$ & $\begin{array}{l}4 / 31 \\
9,42( \pm 8,21) \\
(2,0-44)\end{array}$ \\
\hline $\begin{array}{l}\text { ACPA } \\
\geq 1,26\end{array}$ & $\begin{array}{l}23 / 12 \\
1,71( \pm 0,69) \\
(0,92-3,0)\end{array}$ & $\begin{array}{l}11 / 7 \\
1,56( \pm 0,59) \\
(0,93-2,6)\end{array}$ & $\begin{array}{l}12 / 5 \\
1,87( \pm 0,77) \\
(0,92-3,0)\end{array}$ & $\begin{array}{l}1 / 34 \\
0,95( \pm 0,10) \\
(0,90-1,38)\end{array}$ \\
\hline
\end{tabular}

Table 1: AAP,y-GT, $\beta 2 \mathrm{M}$ and other laboratory variables in $\mathrm{RA}$ and control healthy group.

\begin{tabular}{|c|c|c|c|c|c|c|c|c|c|c|c|c|c|c|c|}
\hline & $\begin{array}{c}\text { AAP } \\
\text { RA No35 }\end{array}$ & $\begin{array}{c}\text { AAP } \\
\text { RA No18 }\end{array}$ & $\begin{array}{c}\text { AAP } \\
\text { RA }^{+} \text {No17 }\end{array}$ & \multicolumn{2}{|c|}{$\begin{array}{c}\text { y GT } \\
\text { RA No35 }\end{array}$} & \multicolumn{2}{|c|}{$\begin{array}{c}\text { Y GT } \\
\text { RA- No18 }^{-}\end{array}$} & \multicolumn{2}{|c|}{$\begin{array}{c}\text { y GT } \\
\text { RA }^{+} \text {No } 17\end{array}$} & \multicolumn{2}{|c|}{$\begin{array}{c}\beta 2 \\
\text { Microglobulin } \\
\text { RA No } 35\end{array}$} & \multicolumn{2}{|c|}{$\begin{array}{c}\beta 2 \\
\text { Microglobulin } \\
\text { RA- }^{-} \text {No } 18\end{array}$} & \multicolumn{2}{|c|}{$\begin{array}{c}\beta 2 \\
\text { Microglobulin } \\
\mathrm{RA}^{+} \text {No } 17\end{array}$} \\
\hline SENSITIVITY \% & 68,57 & 77,77 & 58,82 & & 45,71 & \multicolumn{2}{|c|}{55,55} & \multicolumn{2}{|c|}{35,29} & \multicolumn{2}{|c|}{0} & \multicolumn{2}{|c|}{0} & \multicolumn{2}{|r|}{0} \\
\hline SPECIFICITY \% & 80 & 80 & 80 & & 82,85 & \multicolumn{2}{|c|}{82,85} & \multicolumn{2}{|c|}{82,85} & \multicolumn{2}{|c|}{97,14} & \multicolumn{2}{|c|}{97,14} & & 97,14 \\
\hline $\begin{array}{c}\text { PREDICTIVE VALUES } \\
\text { FOR THE POSITIVE } \\
\text { TEST } \%\end{array}$ & 77,41 & 66,66 & 58,82 & & 72,72 & \multicolumn{2}{|c|}{62,50} & \multicolumn{2}{|c|}{50} & \multicolumn{2}{|c|}{0} & \multicolumn{2}{|c|}{0} & \multicolumn{2}{|r|}{0} \\
\hline $\begin{array}{c}\text { PREDICTIVE VALUES } \\
\text { FOR THE NEGATIVE } \\
\text { TEST } \%\end{array}$ & 28,20 & 2,5 & 0 & & 39,58 & \multicolumn{2}{|c|}{21,62} & \multicolumn{2}{|c|}{27,5} & \multicolumn{2}{|c|}{89,74} & \multicolumn{2}{|c|}{34,61} & & 33,33 \\
\hline \multirow[t]{2}{*}{ PRECISION \% } & 74,28 & 79,24 & 73,07 & & 64,28 & \multicolumn{2}{|c|}{73,58} & & & \multicolumn{2}{|c|}{48,57} & \multicolumn{2}{|c|}{64,15} & & 65,38 \\
\hline & $\begin{array}{l}\text { KREATININE } \\
\text { SERUM } \\
\text { RA No } 35\end{array}$ & 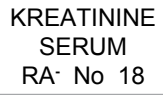 & \multicolumn{2}{|c|}{$\begin{array}{l}\text { KREATININE } \\
\text { SERUM } \\
\text { RA }^{+} \text {No } 17\end{array}$} & \multicolumn{2}{|c|}{$\begin{array}{l}\text { KREATININ } \\
\text { URINA } \\
\text { RA No } 35\end{array}$} & \multicolumn{2}{|c|}{$\begin{array}{l}\text { KREATININ } \\
\text { URINA } \\
\text { RA- No } 18\end{array}$} & \multicolumn{2}{|c|}{$\begin{array}{l}\text { KREATININ } \\
\text { URINA } \\
\text { RA }^{+} \text {No } 17\end{array}$} & \multicolumn{2}{|c|}{$\begin{array}{l}\text { UREA SERUM } \\
\text { RA No } 35\end{array}$} & \multicolumn{2}{|c|}{$\begin{array}{c}\text { UREA } \\
\text { SERUM } \\
\text { RA' No } 18\end{array}$} & $\begin{array}{c}\text { UREA } \\
\text { SERUM } \\
\text { RA }^{+} \text {No17 }\end{array}$ \\
\hline SENSITIVITY \% & 8,57 & 5,55 & \multicolumn{2}{|l|}{11,76} & 25 & & & & & 7,64 & & ,42 & 0 & & 23,52 \\
\hline SPECIFICITY \% & 94,28 & 94,28 & 94,28 & & 85 & & & & & 5,71 & &, 14 & 97 , & & 97,14 \\
\hline $\begin{array}{c}\text { PREDICTIVE VALUES } \\
\text { FOR THE POSITIVE } \\
\text { TEST } \%\end{array}$ & 60 & 33,33 & 50 & & 64, & & & 54 & & 37,5 & & 30 & 0 & & 80 \\
\hline $\begin{array}{c}\text { PREDICTIVE VALUES } \\
\text { FOR THE NEGATIVE } \\
\text { TEST } \%\end{array}$ & 49,23 & 34 & 31,25 & & 46 , & & & & & 1,88 & &, 69 & 34 , & & 27,65 \\
\hline PRECISION \% & 51,42 & 64,15 & 67,30 & & 55 , & & & & & 3,46 & &, 28 & 64, & & 73,07 \\
\hline
\end{tabular}


Citation: Spasovski D, Sotirova T (2014) Renal Enzymes and Microglobulins in Patients with Rheumathoid Arthritis. J Nephrol Ther 4: 185. doi:10.4172/2161-0959.1000185

Page 5 of 8

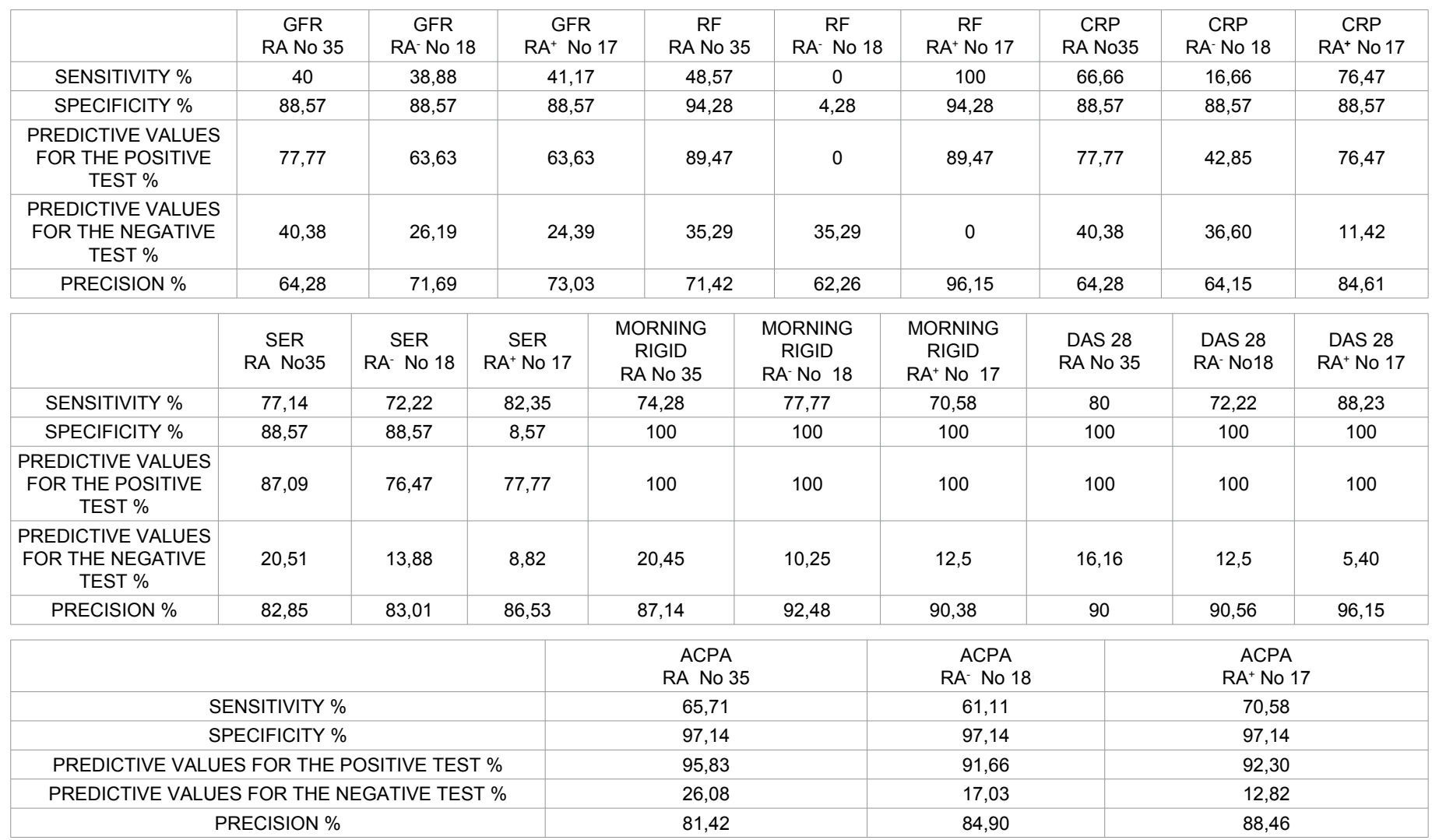

Table 2: Diagnostic performance of AAP, yGT, $\beta 2 \mathrm{M}$ and other laboratory variables in RA.

patients $(88,23 \%)$. Of these 15 patients (DAS $28>3.2$ ), AAP was positive in 8 patients $(53.33 \%)$ and its $\mathrm{M} \pm \mathrm{SD}(1.20 \pm 0.49)$ in extent $(0.80$ $2.30), \gamma$-GT was positive in 4 patients $(26,66 \%)$ and its $\mathrm{M} \pm \mathrm{SD}(2.61 \pm$ 1.07 ) extent (1.90-4.20). $\beta 2 \mathrm{M}$ was not present in these patients. Of 18 RF negative patients, DAS $28>3.2$ was present in 13 patients $(72,22 \%)$. Among these patients DAS 28>3.2 AAP were positive in $11(84,61 \%)$ and their $\mathrm{M} \pm \mathrm{SD}(1.25 \pm 0.43)$ extent $(0.85-2.46), \gamma$-GT was positive in $9(69,23 \%)$ and their $\mathrm{M} \pm \mathrm{SD}(2.55 \pm 0.4)$ range (0.95-3.45), while $\beta 2 \mathrm{M}$ was not present among them.

1. RF negative patients had higher value of AAP than RF positive patients (Table 1).

$(1,14 \pm 0,48)(0,45-2,46)$ vs $0,98( \pm 0,59)(0,35-2,30)$, but lower DAS 28 index $(4.56 \pm 1.76(1.85-7.03)$ vs $(5.04 \pm 1.33)(2.47-6.83)$. Between these two groups of AAP, there was not statistical correlation $(\mathrm{p}=0,185017)$. However, RF negative patients with DAS $28>3.2$ have much higher AAP than positive RF patients with DAS 28>3.2 (1,25 \pm $0.43)(0.85-2.46)$ vs $(1.20 \pm 0.49)(0.80-2.30)$. Between these two group of AAP there was not statistical correlation $(\mathrm{p}=0,16)$. (Figure 1)

2. RF negative patients did not have higher values of $\gamma$-GT than RF positive (Table 1$)$. $(1,81 \pm 0,80)(0,70-3,50)$ vs $1,79( \pm 1,15)(0,45-4,40)$. Between these two groups in regard of $\gamma$-GT there was not statistical correlation $(p=0,67)$. However, RF positive patients with DAS $28>3.2$ had much higher $\gamma$-GT than RF negative patients with DAS $28>3.2$ $(2.61 \pm 1.07)(1.90-4.20)$ vs $(2.55 \pm 0.46)(0.95-3.45)$. Between these two groups in regard of $\gamma$-GT there was not statistical correlation $(\mathrm{p}=0,72)$ (Figure 2).

3. $\mathrm{RF}$ negative patients had a little higher value of $\beta 2 \mathrm{M}$ than $\mathrm{RF}$ positive patients. (Table 1$)(0.06( \pm 0,04)(0,01-0,15)$ vs $0,04( \pm 0,03)$ $(0,01-0,13)$. Between these two groups in regard of $\beta 2 \mathrm{M}$ there was not statistical correlation $(\mathrm{p}=0,22)$. However, $13 \mathrm{RF}$ negative patients with DAS $28>.2$ had much higher $\beta 2 \mathrm{M}$ than $15 \mathrm{RF}$ positive patients with DAS $28>3.2(0.07 \pm 0.04)(0.01-0.15)$ vs $(0.047 \pm 0.039)(0.01-0.13)$. Between these two groups in terms of $\beta 2 \mathrm{M}$ there was not statistical correlation $(\mathrm{p}=0,22)$ (Figure 3$)$. In RF positive and negative patients there was not statistical correlation between DAS 28 index $(\mathrm{p}=0,379)$.

4. There was statistical correlation between AAP in RA patients and control healthy group using Wilcoxon-matched test $(p=0.026113)$. In RA patients there was statistical correlation between AAP and $\gamma$-GT $(\mathrm{p}=0.00)$; AAP and $\beta 2 \mathrm{M}(\mathrm{p}=0.00) ; \gamma-\mathrm{GT}$ and $\beta 2 \mathrm{M}(\mathrm{p}=0.00)$.

5. There was not statistical correlation between $\gamma$-GT in RA patients and control healthy group $(\mathrm{p}=0.308160), \beta 2 \mathrm{M}$ in RA and healthy control group $(\mathrm{p}=0.05)$.

6. There was not statistical correlation using Wilcoxon-matched test between AAP, age, duration of disease in months, DAS 28 index, RF, CRP, ESR, anti CCP 2, morning stiffness, creatinine in serum and urine and serum urea in the same group: AAP vs age ( $\mathrm{p}=0.00)$; AAP vs duration of disease in months ( $\mathrm{p}=0.000000)$; AAP vs DAS $28 \mathrm{p}=(0,00)$; AAP vs RF ( $p=0,01)$; AAP vs CRP ( $p=0,04)$; AAP vs ESR ( $p=0,00)$; AAP vs anti CCP $2(p=0,00)$; AAP vs morning stiffness $(p=0,00)$; AAP vs serum creatinine $(p=0,00)$; AAP vs urine creatinine ( $p=0,00)$; AAP vs serum urea $(\mathrm{p}=0,00)$.

7. There was not statistical correlation using Wilcoxon-matched test between $\gamma$-GT, age, duration of disease in months, DAS 28 index, RF, CRP, ESR, morning stiffness, creatinine in serum and urine and serum urea; $\gamma$-GT vs age $(\mathrm{p}=0.00) ; \gamma$-GT vs RF $(\mathrm{p}=0,019) ; \gamma$-GT vs duration of disease in months $(\mathrm{p}=0.00) ; \gamma$-GT vs DAS $28(\mathrm{p}=0,00) ; \gamma$-GT vs CRP $(\mathrm{p}=0,04) ; \gamma$-GT vs ESR $(\mathrm{p}=0,00) ; \gamma$-GT vs morning stiffness $(\mathrm{p}=0,00)$; 
AAP AT 8 RA SERO POZITIV PACIENTS WITH DAS $28>3.2$

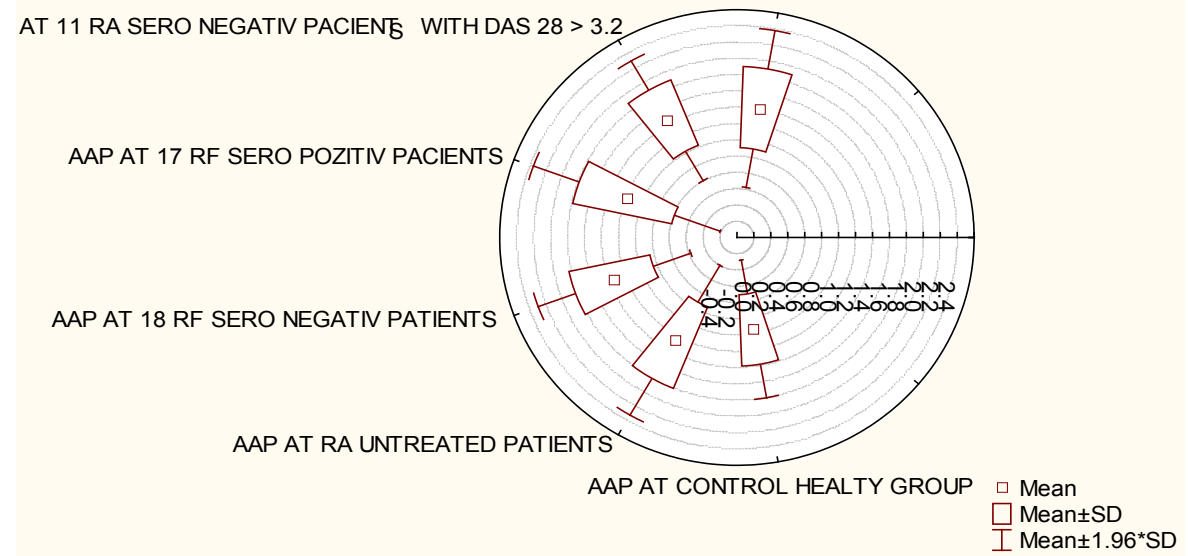

Figure 1: Distribution of alanine amino peptidase (AAP) ( U/mmol creatinine ) in all groups.

$\gamma$-GT AT 4 RF SERO POZITIV PACIENTS WITH DAS $28>3.2$

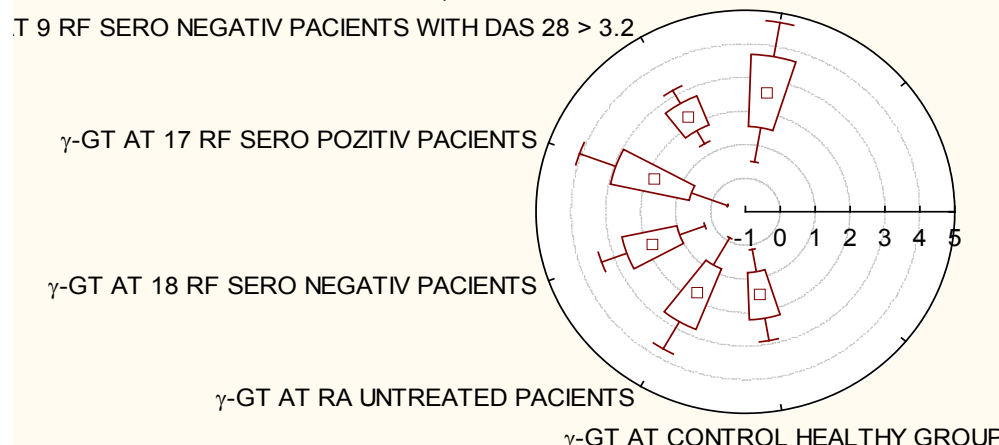

$\gamma$-GT AT CONTROL HEALTHY GROUP



Figure 2: Distribution of -glutamyl transferase ( $\mathrm{y}-\mathrm{GT}$ ) ( $\mathrm{U} / \mathrm{mmol}$ creatinine ) in all groups.

$\beta$-2M AT 15 RF SERO POZITIV PACIENTS WITH DAS $28>3.2$

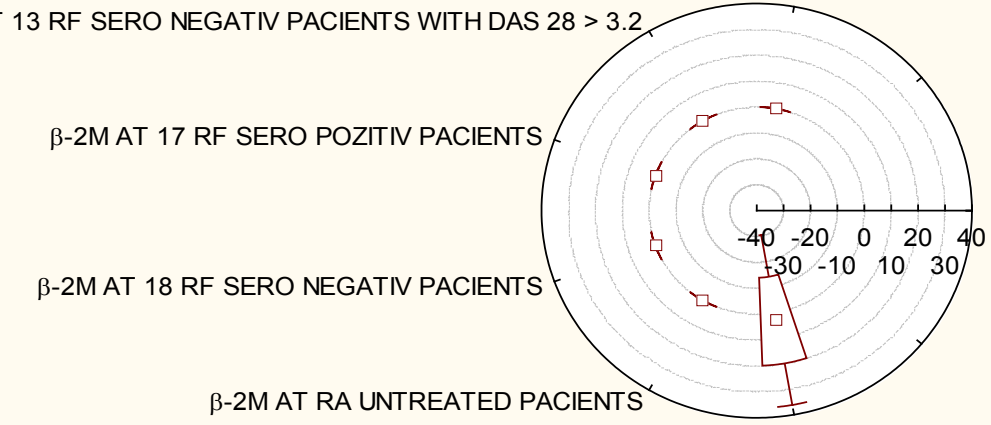

B-2M AT CONTROL HEALTHY GROUP

$$
\begin{aligned}
& \square \text { Mean } \\
& \square \text { Mean } \pm \text { SD } \\
& \text { I Mean } \pm 1.96 * \mathrm{SD}
\end{aligned}
$$

Figure 3: Distribution of $\beta 2$ microglobuline $(\beta 2 \mathrm{M})$ in urine $(\mathrm{mg} / \mathrm{L})$ in all groups. 
$\gamma$-GT vs serum creatinine $(\mathrm{p}=0,00) ; \gamma$-GT vs urine creatinine $(\mathrm{p}=0,00)$ $\gamma$-GT vs serum urea $(\mathrm{p}=0,00)$.

8. There was not statistical correlation using Wilcoxon-matched test between $\beta 2 \mathrm{M}$, age, duration of disease in month, DAS 28 index, RF, CRP, ESR, anti CCP 2, morning stiffness, creatinine in serum and urine and urea serum in the same group: $\beta 2 \mathrm{M}$ vs age $(\mathrm{p}=0.00) ; \beta 2 \mathrm{M}$ vs duration of disease in months $(\mathrm{p}=0.00) ; \beta 2 \mathrm{M}$ vs DAS $28(\mathrm{p}=0,00)$; $\beta 2 \mathrm{M}$ vs $\mathrm{RF}(\mathrm{p}=0,018345) ; \beta 2 \mathrm{M}$ vs $\mathrm{CRP}(\mathrm{p}=0,04) ; \beta 2 \mathrm{M}$ vs $\operatorname{ESR}(\mathrm{p}=0,00$ ); $\beta 2 \mathrm{M}$ vs anti CCP $2(\mathrm{p}=0,00) ; \beta 2 \mathrm{M}$ vs morning stiffness ( $\mathrm{p}=0,00) ; 2 \mathrm{M}$ vs serum creatinine $(\mathrm{p}=0,00) ; \beta 2 \mathrm{M}$ vs urine creatinine $(\mathrm{p}=0,00) ; \beta 2 \mathrm{M}$ vs serum urea $(\mathrm{p}=0,00)$.

9. There was not statistical correlation using Wilcoxon-matched test between $\gamma$-GT and anti CCP 2 in the same group ( $\gamma$-GT vs anti CCP $2(\mathrm{p}=0,49)$.

\section{Discussion}

Elevation in urine enzymes' activity could indicate primary renal tubular damage, because of their location in brush border area, such as microsomal AAP (E.C 3.4.11.2) and tubular lysozyme (NAG E.C.3.2.1.30). They could be used in early diagnosis of acute renal failure caused by immunosuppressive drugs, contrast materials, antibiotics and cadmium exposition [46-52]. Urine enzymatic activity normally is low and is increased in case of the renal tubular damage [53]. Urine enzymes, especially NAG, AAP, AP are very sensitive indicators of renal parenchymal damage in comparison with functional measurements such as glomerular filtration rate (GFR), creatinine and inulin clearance. Relatively low sensitivity of GFR can be explained with large functional kidney and its great compensatory ability [53]. Sensitivity of AAP is higher compared with $\gamma$-GT and $\beta 2 \mathrm{M}(68,57 \%$ vs $45,71 \%$ vs $0 \%)$ with approximately equal specificity ( $80 \%$ vs $82,85 \%$ vs $97,14 \%$ ). The other standard routine analyses used for evaluation of renal function showed low sensitivity (creatinine in serum and urine, serum urea $(8.57 \%$ vs $25.71 \%$ vs $11.42 \%)$. RF negativity had influence on the presence of AAP enzymuria. It was presented in RF negative patients with DAS $28>3.2$ with much higher $\beta 2 \mathrm{M}$ than in RF negative patients with DAS $28>3.2$ $(0.07 \pm 0.04)(0.01-0.15)$ vs $(0.047 \pm 0.039)(0.01-0.13)$, but that was not the case with the intensity of $\gamma$-GT, where RF positivity had different meaning. The duration of the disease in months and AAP, $\gamma$-GT and $\beta 2 \mathrm{M}$ enzymuria $(\mathrm{p}=0.00)$ showed that untreated RA had an influence on renal tissue as one of visceral manifestation of the disease. Enzymes originating from primary damaged proximal tubular brush border area in untreated RA had higher sensitivity.

\section{Conclusion}

AAP has higher sensitivity then $\gamma$-GT and $\beta 2 \mathrm{M}$ in detection of asymptomatic renal damage in untreated RA. AAP and $\gamma$-GT can be used in everyday clinical practice in diagnose of early asymptomatic renal damage.

\section{References}

1. Rosalki SB, Wilkinson $\mathrm{JH}$ (1959) Urinary lactic dehydrogenase in renal disease. Lancet 2: 327-328.

2. Raab W (1966) [Experimental studies on the changes in leucine aminopeptidase activity of the urine].

3. Raab WP (1968) Enzymes and isoenzymes in urine. Curr Probl Clin Biochem 2: $17-83$

4. Maruhn D (1976) Rapid colorimetric assay of beta-galactosidase and N-acetylbeta-glucosaminidase in human urine. Clin Chim Acta 73: 453-461.

5. Scherberich JE, Falkenberg FW, Mondorf AW, Müller H, Pfleiderer G (1974) Biochemical and immunological studies on isolated brush border membranes of human kidney cortex and their membrane surface proteins. Clin Chim Acta 55: 179-197.

6. KLAUS D (1958) [Renal enzyme excretion in proteinuria]. Klin Wochenschr 36: 207-211.

7. Mellman I, Fuchs R, Helenius A (1986) Acidification of the endocytic and exocytic pathways. Annu Rev Biochem 55: 663-700.

8. Wellwood JM, Ellis BG, Price RG, Hammond K, Thompson AE, et al. (1975) Urinary $\mathrm{N}$-acetyl- beta-D-glucosaminidase activities in patients with renal disease. Br Med J 3: 408-411.

9. Mueller PW (1993) Detecting the renal effects of cadmium toxicity. Clin Chem 39: 743-745.

10. Maruhn D, Paar D, Bock KD (1979) Lysosomal and brush border membrane enzymes in urine of patients with renal artery stenosis and with essential hypertension. Clin Biochem 12: 228-220.

11. Vanderlinde RE (1981) Urinary enzyme measurements in the diagnosis of renal disorders. Ann Clin Lab Sci 11: 189-201.

12. Price RG (1982) Urinary enzymes, nephrotoxicity and renal disease. Toxicology 23: $99-134$.

13. Johnston ID, Jones NF, Scoble JE, Yuen CT, Price RG (1983) The diagnostic value of urinary enzyme measurements in hypertension. Clin Chim Acta 133: 317-325.

14. Sandberg T, Bergmark J, Hultberg B, Jagenburg R, Trollfors B (1986) Diagnostic potential of urinary enzymes and beta 2-microglobulin in acute urinary tract infection. Acta Med Scand 219: 489-495.

15. Hiwada K, Terao M, Nishimura K, Kokubu T (1977) Comparison of human membrane-bound neutral arylamidases from small intestine, lung, kidney, liver and placenta. Clin Chim Acta 76: 267-275.

16. Diener U, Knoll E, Langer B, Rautenstrauch H, Ratge D, et al. (1981) Urinary excretion of $\mathrm{N}$-acetyl-beta-D-glucosaminidase and alanine aminopeptidase in patients receiving amikacin or cis-platinum. Clin Chim Acta 112: 149-157.

17. Huseby NE (1978) Multiple forms of gamma-glutamyltransferase in norma human liver, bile and serum. Biochim Biophys Acta 522: 354-362.

18. Shaw LM, Petersen-Archer L, London JW, Marsh E (1980) Electrophoretic, kinetic, and immunoinhibition properties of gamma-glutamyltransferase from various tissues compared. Clin Chem 26: 1523-1527.

19. Shaw LM, London JW, Petersen LE (1978) Isolation of gammaglutamyltransferase from human liver, and comparison with the enzyme from human kidney. Clin Chem 24: 905-915.

20. Portman RJ, Kissane JM, Robson AM (1986) Use of beta 2 microglobulin to diagnose tubulo-interstitial renal lesions in children. Kidney Int 30: 91-98.

21. Berggård I, Bearn AG (1968) Isolation and properties of a low molecular weight beta-2-globulin occurring in human biological fluids. J Biol Chem 243: 40954103.

22. Schardijn GH1, Statius van Eps LW (1987) Beta 2-microglobulin: its significance in the evaluation of renal function. Kidney Int 32: 635-641.

23. Suzuki S1, Sato H, Inomata A, Maruyama H, Ueno M, et al. (1992) Immunohistological localization of beta-2-microglobulin in renal tissue as an indicator of renal dysfunction. Nephron 60: 181-186.

24. Viergever PP1, Swaak AJ (1989) Urine- and serum beta 2-microglobulin in patients with rheumatoid arthritis: a study of 101 patients without signs of kidney disease. Clin Rheumatol 8: 368-374.

25. Vincent C (1990) [Beta 2-microglobulin: structure, function, metabolism and changes in diseases]. Ann Dermatol Venereol 117: 661-668.

26. Williams RC Jr1, Nissen MH, Malone CC (1993) Rheumatoid factors from patients with rheumatoid arthritis react with Des-Lys58-beta $2 \mathrm{~m}$, modified beta 2-microglobulin. Clin Exp Immunol 92: 419-424.

27. Evrin PE, Wibell L (1972) The serum levels and urinary excretion of 2 -microglobulin in apparently healthy subjects. Scand J Clin Lab Invest 29: 6974.

28. Crisp AJ, Coughlan RJ, Mackintosh D, Clark B, Panayi GS (1983) beta 2 microglobulin plasma levels reflect disease activity in rheumatoid arthritis. J Rheumatol 10: 954-956. 
Citation: Spasovski D, Sotirova T (2014) Renal Enzymes and Microglobulins in Patients with Rheumathoid Arthritis. J Nephrol Ther 4: 185. doi:10.4172/2161-0959.1000185

Page 8 of 8

29. Weissel M, Scherak O, Fritzsche H, Kolarz G (1976) Letter: Serum beta2microglobulin and SLE. Arthritis Rheum 19: 968.

30. Descos L, André C, Beorghia S, Vincent C, Revillard JP (1979) Serum levels of beta-2-microglobulin--a new marker of activity in Crohn's disease. $\mathrm{N}$ Engl $\mathrm{J}$ Med 301: 440-441.

31. Renaudineau Y1, Jamin C, Saraux A, Youinou P (2005) Rheumatoid factor on a daily basis. Autoimmunity $38: 11-16$.

32. Van Gestel AM, Prevoo ML, Van 't Hof MA, van Rijswijk MH, van de Putte LB,et al (1996) Development and validation of the European League Agains Rheumatism response criteria for rheumatoid arthritis. Comparison with the preliminary American College of Rheumatology and the World Health Organization/International League against Rheumatism Criteria. Arthritis Rheum 39: 34-40.

33. Prevoo ML, van 't Hof MA, Kuper $\mathrm{HH}$, van Leeuwen MA, van de Putte LB, et al.(1995) Modified disease activity scores that include twenty-eight-joint counts. Development and validation in a prospective longitudinal study of patients with rheumatoid arthritis. Arthritis Rheum 38: 44-8.

34. Balsa A1, Carmona L, González-Alvaro I, Belmonte MA, Tena X, et al. (2004) Value of Disease Activity Score 28 (DAS28) and DAS28-3 compared to American College of Rheumatology-defined remission in rheumatoid arthritis. J Rheumatol 31: 40-46.

35. Prevoo ML, van Gestel AM, van T Hof MA, van Rijswijk MH, van de Putte LB,et al.(1996) Remission in a prospective study of patients with rheumatoid arthritis. American Rheumatism Association preliminary remission criteria in relation to the disease activity score. Br J Rheumatol 35: 1101-5.

36. Bailie GR, Uhlig K, Levey AS (2005) Clinical practice guidelines in nephrology: evaluation, classification, and stratification of chronic kidney disease. Pharmacotherapy 25: 491-502.

37. Singer JM, Plotz CM, Pader E, Elster SK (1957) The latex-fixation test. III. Agglutination test for C-reactive protein and comparison with the capillary precipitin method. Am J Clin Pathol 28: 611-617.

38. Hokama Y, Nakamura RM. C-Reactive protein: current status and future perspectives (1987). J Clin Anal 1: 15-27.

39. Young DS, Thomas DW, Friedman RB, Pestaner LC (1972) Effects of drugs on clinical laboratory tests. Clin Chem 18: 1041-1303.

40. PLOTZ CM, SINGER JM (1956) The latex fixation test. I. Application to the serologic diagnosis of rheumatoid arthritis. Am J Med 21: 888-892.
41. Shmerling RH, Delbanco TL (1991) The rheumatoid factor: an analysis of clinical utility.Am J Med 91: 528-534.

42. Szasz G (1969) A kinetic photometric method for serum gamma-glutamyl transpeptidase. Clin Chem 15: 124-136.

43. Orlowski M, Meister A (1963) Gamma-Glutamyl-P-Nitroanilide: A new convenient substrate for determination and study of L- and D-GammaGlutamyltranspeptidase activities. Biochim Biophys Acta 73: 679-681.

44. Persijn JP, van der Slik W (1976) A new method for the determination of gamma-glutamyltransferase in serum. J Clin Chem Clin Biochem 14: 421-427.

45. Shaw LM, Stromme JH, London JL, Theodorsen L(1983) International Federation of Clinical Chemistry. Scientific Committee, Analytical Section. Expert Panel on Enzymes. IFCC methods for measurement of enzymes. Clin Chim Acta 135: 315-338

46. Dos Santos AC, Colacciopo S, Dal Bó CM, dos Santos NA (1994) Occupational exposure to lead, kidney function tests, and blood pressure. Am J Ind Med 26 : 635-643.

47. Shibasaki T, Nakano H, Ohno I, Ishimoto F, Sakai O (1994) Effect of pentoxifylline on $\mathrm{CdCl} 2$-induced nephrotoxicity in the rat. Biol Trace Elem Res 41: 245-251.

48. Hong CY, Chia KS (1998) Markers of diabetic nephropathy. J Diabetes Complications 12: 43-60.

49. Sherman RL, Drayer DE, Leyland-Jones BR, Reidenberg MM (1983) N-acetylbeta-glucosaminidase and beta 2-microglobulin. Their urinary excretion in patients with renal parenchymal disease. Arch Intern Med 143: 1183-1185.

50. Hultberg B, Ravnskov U (1981) The excretion of N-acetyl-beta-glucosaminidase in glomerulonephritis. Clin Nephrol 15: 33-38.

51. Price RG (1992) Measurement of N-acetyl-beta-glucosaminidase and its isoenzymes in urine methods and clinical applications. Eur J Clin Chem Clin Biochem 30: 693-705.

52. Hofmann W1, Guder WG (1989) A diagnostic programme for quantitative analysis of proteinuria. J Clin Chem Clin Biochem 27: 589-600.

53. Chiu JSP (1994) Models used to assess renal function. Drug Devel Res 32 247-55. 